\title{
A imaginação quadernesca como o palco do Romance d'A Pedra do Reino
}

\author{
Geice Peres Nunes ${ }^{1}$
}

RESUMO: O presente ensaio propõe uma análise comparativa com enfoque nos gêneros narrativo e dramático. Para tanto, toma como corpus o Romance d'A Pedra do Reino (1971), de Ariano Suassuna, e investiga os recursos que proporcionam um efeito dramático na referida obra. Ao contar episódios de sua vida com pinceladas de humor, de heroísmo e de aventura, o narrador protagonista Quaderna imagina a tessitura de um romance que se mostra para o leitor como uma peça encenada devido à plasticidade e ao tom oral e eloquente empregado em seu narrar.

ABSTRACT: This essay proposes a comparative analysis focused on narrative and dramatic genres. Therefore, it is taken as corpus the Romance d'A Pedra do Reino (1971), by Ariano Suassuna, as well as investigated the resources that provide a dramatic effect in mentioned work. In this manner, by telling episodes of his life with humor, heroism and adventure, Quaderna imagines the composition of a novel presented to the reader as an acted play due to the plasticity, the oral and eloquent tone used to narrate.

Palavras-chave: Teatralidade; romance; imaginação.

Keywords: Theatricality; novel; imagination.

No panorama da literatura brasileira contemporânea, Ariano Suassuna notabilizou-se como dramaturgo, ao compor peças como Auto da Compadecida (1957), O santo e a porca (1964), Farsa da boa preguiça (1974), dentre outras. Entretanto, o reconhecimento como mentor do Movimento Armorial deu-se em menor proporção. Esse fato é um tanto lamentável, visto que o conjunto da obra do autor está estritamente vinculado a tal movimento, que se situa entre o popular e o letrado, entre o oral e o escrito, além de desempenhar um papel original, talvez único, na cultura brasileira, conforme foi colocado por Idelette Muzart Fonseca dos Santos (2009, p.21). A originalidade do Armorial

\footnotetext{
${ }^{1}$ Doutoranda em Estudos Literários (UFSM). Bolsista CAPES.
} 
deve-se ao fato de reunir artistas das mais diversas áreas como homens de letras e de teatro, artistas plásticos, músicos, pintores, ceramistas e bailarinos, movidos pelo objetivo de promover uma confluência das artes. Tais artistas realizam uma mescla de diversas expressões artísticas, de estilos antagônicos como o popular e o erudito, além de priorizar em suas obras o desenvolvimento de uma atmosfera de espetáculo. A definição do Armorial, realizada por Ariano Suassuna, é clara em relação às bases que o orientam:

A Arte Armorial é aquela que tem como traço comum principal a ligação com o espírito mágico dos "folhetos", do Romanceiro Popular do Nordeste (Literatura de Cordel), com a Música de viola, rabeca ou pífano que acompanha seus "cantares", e com a Xilogravura que ilustra suas capas, assim como com o espírito e a forma das Artes e espetáculos populares com esse mesmo Romanceiro relacionados. (SUASSUNA, 1977, p.39).

A partir dos traços apontados, o propósito agregador parece mais visível nas produções de Ariano Suassuna. O entrecruzamento das artes a fim de elaborar uma obra em que diversos gêneros apareçam coadunados está presente em grande parte da produção do autor. Em Auto da Compadecida, por exemplo, identificamos a fusão dos folhetos de cordel, dos espetáculos circenses, de traços da commedia dell'arte, da novela picaresca, harmoniosamente dispostos. Já nos entremezes, como $O$ homem da vaca e o poder da fortuna, deparamo-nos com a fusão do mamulengo, dos folhetos de cordel e dos romances medievais e ibéricos. Na poesia de Suassuna, imagética e fonte profunda de tudo o que escreve (SANTIAGO, 2007, p.163), revela-se a ligação com o romanceiro popular, tanto na temática quanto na forma empregada, imbricada com traços da estética barroca.

Perseguindo uma forma artística que permitisse dar vazão àquilo que não conseguia incorporar na poesia e nas peças, Suassuna se lançou à escritura do Romance d'A Pedra do Reino em 1958. Assim, após doze anos de escrita, deu 
concretude a uma obra que concentra a prosa, a poesia erudita e a popular, alguns traços da epopeia, a xilogravura, os acontecimentos históricos revisitados pela literatura, entre outras presenças. Essa mescla foi possível pelo fato de o enredo concentrar em si um metaromance em progresso, no qual Quaderna, o narrador protagonista, romantiza as origens do povo brasileiro. A personagem discute questões de relevância nacional, como o entrecruzamento do português, do indígena e do africano, que deu origem ao povo naturalmente miscigenado; bem como acontecimentos locais, como episódios ocorridos na Vila de Taperoá.

Dentre esses temas, a narrativa ainda apresenta um assassinato a ser elucidado: a morte misteriosa do tio e padrinho de Quaderna, Sebastião GarciaBarretto. O protagonista, acusado desse crime, encontra-se preso, e, na cadeia, rememora e fantasia diversos momentos da sua existência, criando uma espécie de romance imaginário que vai tomando forma à medida que Quaderna presta depoimento e o processo avança.

Desse modo, guiados pelo êxito de Suassuna na qualidade de dramaturgo, bem como pela proposta Armorial, investigamos como a teatralidade está representada no Romance d'A Pedra do Reino. Nesse sentido, cientes nos postulados bakhtinianos acerca do romance enquanto gênero literário e a sua flexibilidade ao incorporar outros gêneros, investigamos como o traço cênico se consolida na obra, ainda que não haja elementos estruturais confirmando essa presença.

\section{A teatralidade no Romance}

A nuança teatral é latente no Romance. A habilidade do narrador e protagonista Pedro Diniz Quaderna em criar um cenário mental, em armar situações e em encená-las aos "nobres senhores e belas damas" - seus leitores/ouvintes - atesta o seu caráter performático, ao mesmo tempo em que concede traços cênicos à obra. Ao fazermos essa afirmação, temos ciência de que o texto dramático é estruturado por marcações que orientam o ato cênico, 
bem como o modo como a ação deve ser conduzida no espetáculo. Entretanto, sendo a produção suassuniana originada de uma recriação a partir dos gêneros populares, nos quais a performance é tão presente, notamos que o autor, por meio da eloquência da personagem, carrega-a de vivacidade ao contar as suas histórias. Isso sugere um movimento de corpo e de impostação vocal tal qual encontramos no desempenhar de um papel dramático.

Quaderna utiliza-se de vários tons discursivos: ora pomposo, ora polido em demasia; hiperbólico em diversos momentos; irônico e jocoso, quando deseja rebaixar a si mesmo ou a outra personagem. Desse desnível, sobressai uma retórica cômica, que tem por objetivo convencer o público, seja na forma de um auditório ou mesmo de leitores do futuro romance, que será publicado com os autos do processo no qual o protagonista está envolvido. Nesse sentido, valendo-se do tom oral - característico das expressões populares -, Suassuna consegue expressar por meio dele, não só o conteúdo do texto, mas também imprimir na personagem o estilo performático do ator.

No estudo da obra, a teatralidade parece se orientar em três níveis: primeiramente, no estabelecimento do sertão nordestino como o cenário de sua ação; em segundo lugar, na exposição do enredo, ou seja, das circunstâncias que Quaderna relata no seu discurso; e, finalmente, no esclarecimento do seu objetivo enquanto narrador de uma história plena de tramas. Assim, o protagonista é movido pelo desejo de convencer os "ouvintes" de sua inocência na investigação acerca do assassinato de seu tio e padrinho Sebastião GarciaBarretto.

Quando observamos a finalidade do mise en scène de Quaderna, notamos que a persuasão de seu interlocutor é a meta que ele deseja atingir, por isso, ele interpreta (em um sentido dramático) aquilo que diz. Esse traço se presentifica nas suas enunciações que revelam o efeito pretendido. Assim, em um tempo presente, encarcerado, numa espécie de reflexão, Quaderna encarna um "contador de histórias" na medida em que encadeia os fatos e os expõem aos interlocutores. Esses se configuram como leitores da obra, que assumem um 
papel ambíguo entre leitor e espectador pelo modo como o narrador se dirige a eles:

Escutem, pois, nobres Senhores e belas Damas de peitos brandos, minha terrível história de amor e de culpa: de sangue e de justiça; de sensualidade e violência; de enigma, de morte e disparate; de lutas nas estradas e combates nas Caatingas, história que foi a suma de tudo o que passei e que terminou com os meus costados aqui, nesta Cadeia Velha da Vila Real da Ribeira do Taperoá, Sertão dos Cariris Velhos da Capitania e Província da Paraíba no Norte (SUASSUNA, 2007, p. 35).

A expressão "escutem", do excerto acima, evidencia a ambiguidade de Quaderna. O protagonista parece assumir o papel de um mestre de cerimônias que anuncia o espetáculo ou mesmo uma performance teatral. Parece lançar-se em um monólogo cujas ações se realizam enquanto o sujeito rememora alguns eventos. A certeza obtida a respeito do ser fictício é a de que somos envolvidos pelo seu narrar e conduzidos por ele no universo sertanejo reproduzido na obra, uma atmosfera solar que concentra o pitoresco do sertão nordestino, altamente valorizado e tratado de modo extremamente fantasioso. Quaderna revela, pela sua narrativa, um ambiente tragicômico, onde a mais dura realidade provoca o riso, um lugar onde a fome e a sede jamais são mencionadas. Dessa forma, sua retórica assemelha-se a do cantador popular: chama o público para ouvi-lo, faz um breve resumo de tudo o que irá contar, desperta a curiosidade e dramatiza as ações. Assim, seu procedimento se converte em uma história "desversada", evidenciando a transfiguração do modelo poético que adota. Ainda é possível notar a imersão crescente de Quaderna no espaço dramático, "quando de simples narrador passa a personagem central, assumindo o destino da obra e a memória do autor" (SANTOS, 2009, p. 257).

Para diferenciar os gêneros em questão, drama e romance, Décio de Almeida Prado (2007, p.83), observando-os, afirma que existem semelhanças 
óbvias, já que ambos narram uma história, contam algo que aconteceu em determinado lugar, em um tempo específico, para certo público. Essa proximidade facilita a adaptação da obra literária para o palco. Prado (2007, p.84) esclarece que, na busca de um ponto de diferenciação entre romance e teatro, a personagem é o elemento que permite distinguir um do outro, já que no romance ela é uma instância entre várias, ainda que seja a principal. Entretanto, no teatro, as personagens compõem quase que a totalidade da obra, pois o que é mostrado está mediado por elas. Em alguns casos, como nas peças shakesperianas, por exemplo, o próprio cenário é apresentado por intermédio da personagem, onde a evocação dos lugares é sugerida nos diálogos. Conforme o estudioso, ambos os gêneros falam do homem, no entanto, no dramático, isso é feito pelo próprio homem presentificado no ator.

Nesse sentido, apreendemos o narrador-personagem d'A Pedra do Reino como uma coluna de sustentação da narrativa, por isso, faz-se necessário evidenciar o percurso de Quaderna ao longo desse romance. É graças ao protagonista que as ações se desenrolam de modo bem particular: na sua imaginação transfiguradora. Logo, esse componente da prosa aproxima-se do ator teatral; o Quaderna protagonista se mostra à semelhança da personagem que se expõe no palco e dirige-se diretamente ao público, dispensa a mediação de um narrador; mostra a sua história como se fosse a realidade de fato. Esse comportamento proporciona "a vantagem específica do teatro, tornando-o particularmente persuasivo às pessoas sem imaginação suficiente para transformar, idealmente, a narração em ação" (PRADO, 2007, p.85).

Nesse viés, a narrativa em questão exige de seu leitor (orientado pela imaginação de Quaderna) a criação mental de um palco, no qual toda a ação se desenrola. Esse traço é salientado pelo caráter sinestésico da obra, pois ao mergulharmos no texto, percebemos a musicalidade que provém não só das palavras, mas dos instrumentos sertanejos como o pífano e a rabeca que acompanham as cantorias; a atmosfera sertaneja, da qual emana um calor, provocado pela alusão às cores amareladas e ocres, ao cenário pedregoso, à vegetação rasteira e ao sol escaldante; e a visualização da cena, amparada pelas 
referidas sensações. Tais elementos aguçam os sentidos, permitindo ao leitor recriar esse cenário mentalmente.

Ao investigar a dramaticidade do Romance é importante considerar a posição de Idelette dos Santos $(2009$, p. 260) acerca das peças de Suassuna. Para a pesquisadora, dentre os aspectos intrínsecos do teatro suassuniano, destacamse: a dedicatória, que pode ser musical, cantada e dançada por todas as personagens; a explicação, retomada no início de cada ato pelo curinga, que expressa o objetivo do texto; o episódio, que corresponde ao ato; a cena, revestida de diversas formas, de diálogos ou mímicas ou monólogos, sempre estruturados de acordo com a perspectiva global do ato; o comentário, geralmente em forma de canção; a entrevista; e a exortação ou finalização do ato, retomada no final da peça pelo curinga. Nesse sentido, o curinga mencionado, quando transposto para a narrativa, aproxima-se da figura de Quaderna, que se desdobra em narrador e em protagonista. Além disso, a estrutura da obra lembra a montagem teatral quando observamos que se inicia por uma apresentação, que é uma espécie de resumo de todas as ações da peça. Cada folheto parece equivaler a uma cena, pois cada uma dessas divisões concentra um tema específico; já o comentário equivale ao aparte, ou seja, o discurso proferido por Quaderna e direcionado ao seu interlocutor. Assim, ainda que alguns elementos não se evidenciem tão claramente, grande parte deles está presente na narrativa e permitem a aproximação entre ambos os gêneros.

A primeira descrição espacial que o leitor encontra no Romance, faz alusão a um espaço tipicamente sertanejo, a Vila de Taperoá. Essa apresentação revela a aridez da terra e a adaptação do homem ao cenário descrito por um tom melancólico de quem conhece as agruras da existência no lugar. As palavras que caracterizam o local sugerem certa hostilidade do espaço: o espinho que fere, as pedras que dificultam o deslocamento, o sol demasiadamente quente. Assim, o ambiente, ainda que agressivo, configura-se como uma espécie de refúgio para seres deslocados: o boi (fugido de alguma 
fazenda), o cangaceiro (destinado à vida errante), o beato (temido pelo forte messianismo) e os sertanejos que se veem emparedados no imenso sertão:

Daqui de cima, no pavimento superior, pela janela gradeada da Cadeia onde estou preso, vejo os arredores da nossa indomável Vila sertaneja. O Sol treme na vista, reluzindo nas pedras mais próximas. Da terra agreste, espinhenta e pedregosa, batida pelo Sol esbraseado, parece desprender-se um sopro ardente, que tanto pode ser o arquejo de gerações e gerações de Cangaceiros, de rudes Beatos e Profetas, assassinados durante anos e anos entre essas pedras selvagens, como pode ser a respiração dessa Fera estranha, a Terra - essa Onça-Parda em cujo dorso habita a Raça piolhosa dos homens. Pode ser, também, a respiração fogosa dessa outra Fera, a Divindade, Onça-Malhada que é dona da Parda, e que, há milênios, acicata a nossa Raça, puxando-a para o alto, para o Reino e para o Sol (SUASSUNA, 2007, p. 31).

O sertão, caracterizado inicialmente como um ambiente agressivo, análogo à Onça, aos poucos é ornamentado pela fantasia e a "onça" é domesticada. Do mesmo modo, as descrições espaciais adquirem a função de rubricas $^{2}$, no momento em que o cenário é descrito com minúcia. Assim, percebemos que a mente de Quaderna é um palco ricamente montado, constantemente iluminado pelo refletor de um sol sertanejo, enfeitado pelas pedras e xique-xiques, que se torna um espaço dramático no momento em que o protagonista passa a contar o seu drama.

Ao encarnar o contador de histórias, Quaderna se volta para o tempo passado, recupera o tom oral e narra situações vistas ou ouvidas, talvez não exatamente como ocorreram, mas como ele transforma na imaginação. Com essa conduta, assemelha-se ao narrador descrito por Walter Benjamin, aquele

2 Rubricas são informações presentes no texto dramático, que explicam a cena como posição dos atores no palco, a atmosfera que caracteriza a cena, saídas ou entradas de personagens, dentre outros aspectos. 
que relata experiências adquiridas nas viagens ou ouvidas de outros membros da sua própria comunidade:

A experiência que passa de pessoa a pessoa é a fonte que recorrem todos os narradores. E, entre as narrativas escritas, as melhores são as que menos se distinguem das histórias orais contadas pelos inúmeros narradores anônimos. Entre estes existem dois grupos, que se interpenetram de múltiplas maneiras. A figura do narrador só se torna plenamente tangível se temos presentes esses dois grupos. "Quem viaja tem muito que contar", diz o povo, e com isso imagina o narrador como alguém que vem de longe. Mas também escutamos com prazer o homem que ganhou honestamente sua vida sem sair do seu país e que conhece suas histórias e tradições. (BENJAMIN, 1994, p.198)

No Romance d'A Pedra do Reino, o Livro III, intitulado “Os três irmãos sertanejos", apresenta como eixo estrutural, o depoimento de Quaderna a respeito de alguns acontecimentos importantes no povoado. Por tal aspecto, a narração inicia com a seguinte ideia:

Assim, tudo estava decidido, todos os alicerces traçados, para quando chegasse o momento. Terminou a explicação acadêmica e já se entenderam os motivos que me levaram a erguer este meu Castelo perigoso, literário, espinhento e pedregoso. Posso voltar, portanto, à chegada do Rapaz-doCavalo-Branco e aos motivos da Cadeia em que me acho trancafiado (SUASSUNA, 2007, p. 245).

Paul Zumthor (1993, p. 19), concentrando-se nos efeitos da oralidade, define o termo performance. Sob a sua ótica, a situação performática se dá quando a comunicação e a recepção coincidem no tempo, ou seja, quando o poeta ou seu intérprete cantam de memória e quando a voz se configura como o 
objeto que atesta a performance; do contrário, quando a comunicação se dá por meio da leitura de um texto, o escrito representa a autoridade e, nesse sentido, a escritura é que se liga à performance. Tal ideia é expressa nos seguintes termos:

Tecnicamente a performance aparece como uma ação oral-auditiva complexa, pela qual uma mensagem poética é simultaneamente transmitida e percebida, aqui e agora. Locutor, destinatário(s), circunstâncias, acham-se fisicamente confrontados, indiscutíveis. Na performance, recortam-se os dois eixos de toda comunicação social: o que reúne o locutor ao autor; e aquele sobre o qual se unem situação e tradição (ZUMTHOR, 1993, p.222).

Sendo assim, se a autoridade mencionada por Zumthor está relacionada ao modo como a informação chega ao receptor do texto, o caráter performático da voz de Quaderna se confirma a cada palavra que ele pronuncia no interrogatório. Quando Quaderna abandona a posição de narrador e passa a protagonizar a cena, os diálogos longos e bem articulados reivindicam do leitor a leitura em voz alta, a fim de notar a perfeita retórica ou o jogo irônico que o protagonista põe em prática:

- O senhor é Pedro Dinis Quaderna, Diretor da Biblioteca Municipal Raul Machado?

- Sou sim senhor! - balbuciei como pude.

E acrescentei logo, para me impor como pessoa de pró e homem de bem:

- Mas, além disso, sou ainda redator da Gazeta de Taperoá, jornal conservador e noticioso no qual me encarrego da página literária, enigmática, charadística e zodiacal. Posso dizer, assim, que, além de Poeta-escrivão e bibliotecário, sou jornalista, Astrólogo, literato oficial de banca aberta, consultor sentimental, Rapsodo e diascevasta do Brasil! 
- Rapsodo? - estranhou o Corregedor, com um ar entre enojado e perplexo. - Diascevasta? Que é isso? Que é discevasta? (SUASSUNA, 2007, p. 337)

Essa propriedade pode ser inferida na leitura de Santos acerca do Armorial e de suas particularidades:

Nenhuma arte permite aproximar-se mais da "armorialidade" do que o teatro: seu caráter essencialmente oral reencontra, se não a improvisação, pelo menos a riqueza do canto e a música das palavras. A encenação realiza, em outro nível e numa perspectiva diferente, a mesma integração das artes: poesia, música e artes plásticas. [...] Essa exemplar "armorialidade" do teatro se comprova no texto, enquanto reescritura parcial do folheto da literatura de cordel, bem como nos processos de integração de elementos diversos, emprestados dos espetáculos populares, para culminar na encenação (SANTOS, 2009, p. 221).

Inês Cardoso (2005, p.103), ao discorrer sobre a postura de Quaderna na composição teatral As conchambranças de Quaderna (1988), aponta que seu primeiro movimento é o de abrir a peça. Ele assume o papel de narrador, apresentando-se e apresentando o espaço em que as histórias de desenrolam. Após concluir as apresentações e algumas elucidações que julga importantes, Quaderna abre mão da narração, para atuar com as demais personagens, protagonizando a cena e se instalando em um espaço e um tempo diferenciados da narração.

Assim, conforme Cardoso, esse posicionamento de Quaderna assemelhase à prática do "Teatro do Pobre", modalidade em que há a necessidade de desdobramento de um ator em várias personagens, sendo isso visível e percebido pelo povo. O espectador deve estar consciente de que o ator lança mão de um disfarce geralmente limitado, como uma capa ou um chapéu. Ao 
ator em questão, pode ser atribuída a função de curinga (SANTOS, 2009, p. 258). Semelhantemente, no romance, Quaderna divide-se em dois: enquanto o narrador encontra-se "esfarrapado, sujo, prematuramente envelhecido" (SUASSUNA, 2007, p. 34), o protagonista veste-se com um gibão, valorizado como um traje de gala, sendo, desse modo, mais uma vez identificado o recurso teatral permeando o romance.

Quando voltamos nosso olhar para o Quaderna protagonista, percebemos que nos é permitida uma analogia à ideia bakhtiniana do bufão como "o rei do mundo às avessas" (BAKHTIN, 2008, p.325). Notamos que, em certo sentido, aproxima-se da postura de Quaderna, pois encarnar essa personagem permite

o direito de não compreender, de confundir, de arremedar, de hiperbolizar a vida; o direito de falar parodiando, de não ser literal, de não ser o próprio indivíduo; o direito de conduzir a vida pelo cronotopo intermediário dos palcos teatrais, de representar a vida como uma comédia e as pessoas como atores; o direito de arrancar as máscaras dos outros, finalmente, o direito de tornar pública a vida com todos os seus segredos mais íntimos. (BAKHTIN, 1993, p.278).

Portanto, amparados pela colocação de Bakhtin, entendemos que, ao encarnar o bufão, Quaderna tenta, por meio de suas falas, convencer seu interlocutor da inocência. Nessa investida pela persuasão, embatem-se dois discursos: o acusatório, do Corregedor, e o seu, o defensivo. Aí reside também um jogo retórico que beira ao efeito teatral: dois indivíduos que dominam a arte da palavra e que fazem dela uma arma. No confronto, o comportamento ora eloquente, ora popularesco de Quaderna, revela um traço cômico, aproximando-se do movimento mecânico do boneco de mola, que Bergson compara como uma mola moral, uma ideia manifestada, que se comprime e se entende, tal qual a fala. Quando o fluxo da fala perde o controle, a comicidade se acentua, pelo movimento desordenado, ou pela simples repetição 
(BERGSON, 1987, p. 43). Tal repetição revela elementos morais requintados e espiritualizados, carregados à esfera dos sentimentos e das ideias (1987, p.44).

A partir dos elementos destacados, apontamos traços latentes de teatralidade no romance e percebemos que tal aproximação é perfeitamente sustentável. O olhar comparativo permitiu ver que certos elementos estruturais próprios das peças teatrais, perpassavam o romance: a criação do cenário; a função desempenhada por Quaderna, enquanto narrador e protagonista; o diálogo constante com o seu leitor/espectador; a oralidade do discurso, dentre outros aspectos.

Desse modo, vimos que, mesmo dedicando-se ao gênero romanesco, Ariano Suassuna não descartou a fórmula bem sucedida da sua dramaturgia. Assim, tal qual a proposta Armorial, imbricou o teatro e o romance, tornando concreta a confluência de gêneros artísticos independentes.

\section{Referências bibliográficas:}

BENJAMIN, Walter. O Narrador: Considerações sobre a obra de Nikolai Leskov. In: - Magia e Técnica, arte e política: ensaios sobre literatura e história da cultura. São Paulo: Brasiliense, 1994, p. 197-221.

BERGSON, Henri. O Riso. Rio de Janeiro: Editora Guanabara, 1987.

CARDOSO, Inês. Quaderna: um personagem entre narração e atuação. In: RABETTI, Beti. Teatro e comicidades: estudos sobre Ariano Suassuna e outros ensaios. Rio de Janeiro: 7 Letras, 2005, 103-108.

PRADO, Décio de Almeida. A personagem no teatro. In: CANDIDO, Antonio [et al.]. A personagem de ficção. São Paulo: Perspectiva, 2007, p.81-101.

SANTOS, Idelette Muzart Fonseca. Em demanda da poética popular: Ariano Suassuna e o Movimento Armorial. Campinas: Unicamp, 2009.

SUASSUNA, Ariano. O Movimento Armorial. In: Revista Pernambucana de Desenvolvimento. Recife: 4 (1):39-64, jan./jun. 1977. 
Romance d'A Pedra do Reino e o príncipe do sangue do vai-e-volta. Rio de Janeiro: José Olympio, 2007.

ZUMTHOR, Paul. A letra e a voz. São Paulo, Companhia das Letras, 1993. 